\title{
長石に関する最近の知裁 (3)
}

\author{
U 田 久 政 \\ (宋京工業大学)
}

\section{成琵石の同質異像の発見}

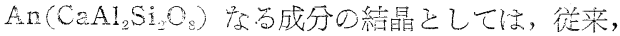

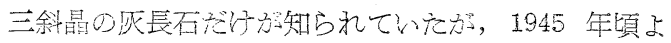

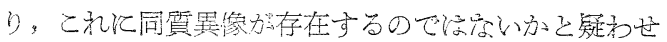

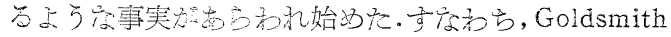
之 Ehlers $\mathrm{CaAl}_{2} \mathrm{Si}_{2} \mathrm{O}_{8}-\mathrm{H}_{2} \mathrm{O}$ 系の平衡関係老研究

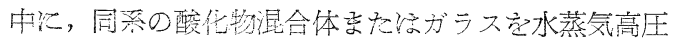

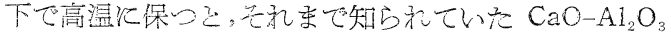
$-\mathrm{SiO}_{2}-\mathrm{H}_{2} \mathrm{O}$ 系のどの結晶をも合致し虸い種属不明の ものが生じること笔見し，京た，Davis-Tuttleらす 斜長石系の固相線以下の相平衡関䋆党研究中, 飞富光配合物在 $1000^{\circ} \mathrm{C}$ 附近火保つ之，そのうち江不

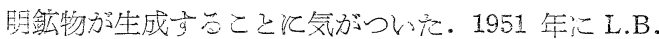
Wyckoff は, 多量のAn 成分のガラス空素気流中

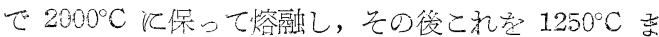
て䢔冷したところ，2種の種属不明の結晶が生じたこ

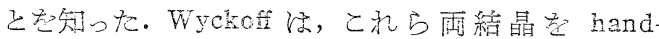
picking そょり採り分けて，地球物理学実験所 (Geophysical Laboratory) 江送り鑑定诖㳖賴した。乞 で，同実験所の Bowen・Davis•Tuttle•Donnay•Sch-

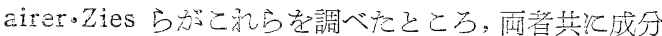

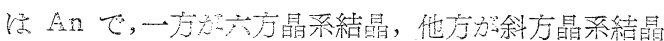

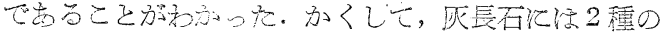

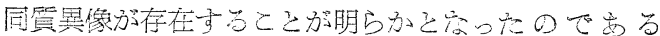

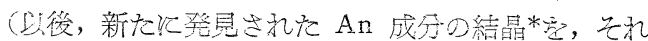

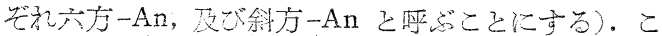
の新知識淿るとづき，前述の Goldsmith らや Davis らがからて指摘した不明結晶学再検討してところ，前 者は六方 $-A n$, 後者注六方 $-A n$ と斜方一Anで者るこ とがわかった。

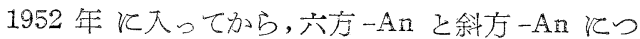
いて，多くの学者がさらに進えだ研究を相ついで発表 した。

孔ず Donnay 活，Weissenberg X 線分光計症用

*こ机らを“長石”を呼ぶことは道当でない。なん となれば，六礼らを一般の喜石族鉣物之比较して 見ると, 内部構造的飞も外形的汇もいらぢるしく 相暴する加占で怘る。このととは，後述するパラ セルシアン・六方セルシアン等についてを同様で 岕る。
いて, 六方 - An の内部構造在研究し ${ }^{(0)}$, その空間群

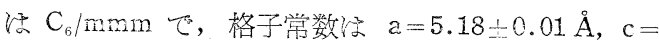
$2 \times 7.36 \pm 0.01 \AA$ そ測定乙た。

ついて Goldsmith そ Ehlers は, $\mathrm{CaAl}_{2} \mathrm{Si}_{2} \mathrm{O}_{8}-\mathrm{H}_{2} \mathrm{O}$ 系の研究発表江際し, 正長石と六方 - An その平衡哭 係について詳細汇論及した ${ }^{41)}$. 彼はAn 成分の酸化物 混合体とガラス表，水蒸気高圧下で $220^{\circ} \sim 504^{\circ} \mathrm{C}$ 間の

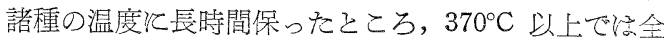

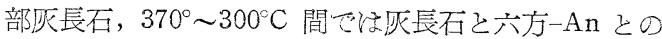
混合物, $300^{\circ} \mathrm{C}$ 以下でほ六方 - An の及が生じること

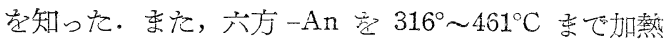

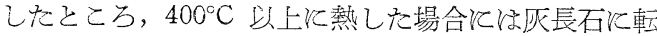
移するが，それ以下の加熱温度では転移が起らなかっ た。これらの結果は, 六方 -An が死長石江比乙て低 温度で安定な form でですることを示すようとも思光 るが，乙かし，これだけで最終的の結論は得られな

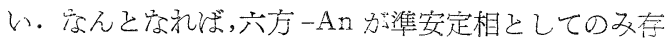
在し, 安定な温度領域を持た京いるのである可能性す 残るからである。特汇，六方一An が天然汇産出した 記録がぜんぜえ無いことほ，後者の可能性を支持す る*. Goldsmith ら络, 灰長石は少なくをも $350^{\circ} \mathrm{C}$ 以

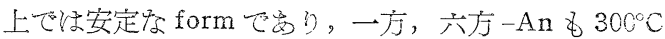
くらいより下洝定な温度範囲が怘らうと推察してい るが，亲だ確定的学結諭ね下していない。

Davis そ Tuttle は， Goldsmith らの論文とほと えぞ同時住, 宍方 $-A n$ と斜方 $-A n$ との光学性・X 線的性質等江関す含詳細な研究結果定発表した ${ }^{42}$ (第5 表). Davis らは, An 飞远い斜長石成分のガラス 液相線より相当低温度 $\left(900^{\circ} \mathrm{C}\right.$ 前後) て失透させて斜 方一An 起生成させるこ己成功したが，乙の際，純 粋な $\mathrm{An}$ 成分のガラスよりも $\mathrm{Ab}_{10} \mathrm{An}_{90} \sim A \mathrm{Ab}_{70} \mathrm{An}_{30}$ 間 の成分のガラス老失透させ場合の方が，豊富飞斜方 一Anを生じることがわかった。

ここに注目すべきほ， $A b$ 分の相当入っているガう スより生成した斜方晶系鉱物は, 純粋尔斜方 - An $飞$

* 天然産のAn 分飞富屯鉡長石が熱水作用( 和气 らく $300^{\circ} \mathrm{C}$ 以下）を受けると， ロヨソン石・䝮廉 石・沸石等の低温度鉣物の集合体飞変化する。こ れをソーシュル石化作用 (saussuritization) 之呼 び，極めて頻繁飞見られる現象で岕当が，そのう

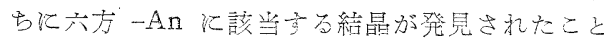
がない。 
第 5 表 六方 $-\mathrm{An}$, 斜方 $-\mathrm{An}$ の諸 恒数 (Davis と Tuttle の 1952 年の 論文中に記載して岕るもの)。

\begin{tabular}{|c|c|c|}
\hline & 六 方 $-A n$ & 斜方 $-A n$ \\
\hline $\begin{array}{l}\text { 剭 } \\
\text { 折 } \\
\text { 率 }\end{array}$ & $\begin{array}{l}\omega=1.585 \\
\varepsilon=1.590\end{array}$ & $\begin{array}{l}\alpha=1.553 \\
\beta=1.580 \\
\gamma=1.584\end{array}$ \\
\hline $2 \mathrm{~V}$ & $0^{\circ}$ & $39^{\circ}$ \\
\hline 光学性 & 正 & 真 \\
\hline $\begin{array}{l}\text { 格 } \\
\text { 子 } \\
\text { 常 } \\
\text { 数 }\end{array}$ & $\begin{array}{c}\mathrm{a}=5.110 \pm 0.02 \AA \\
\mathrm{c}=2 \times 7.367 \pm 0.02 \AA \\
Z=1\end{array}$ & $\begin{array}{c}a=8.224 \pm 0.006 \AA \\
b=8.606 \pm 0.006 \AA \\
c=4.836 \pm 0.005 \AA \\
Z=2\end{array}$ \\
\hline $\begin{array}{l}\text { 比 } \\
\text { 重 }\end{array}$ & 2.77 & 2.70 \\
\hline
\end{tabular}

比して明膫屈折率が低いことで,これ机斜方 - An 汇 も若干量の $\mathrm{Ab}$ 分が固溶し得ること老暗示する。この こそね， $\mathrm{Ab}$ 分分増加するにつれて， $\left(2 \theta_{002}-2 \theta_{021}\right)$ の值が規則正しく変化することとより確諗された。同 様なこと六方 -An そついても方るらしく，この場 合汇々，Ab 分が固溶すると $d_{004}$ の值が規則正しく変 化することとより確められている.An 成分の同質異 像間の平衡関係炕ついては，Davisらも委だはっきり した結論江到達していない。彼らは, Goldsmithらと

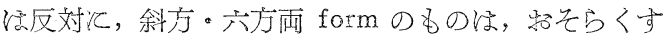
べての温度領域で不安定なもと推察している。

わが国でも，最近，吉木交平博士と小出重明・脇正 教氏らはAn成分の結晶につき研究を行い, 諸種の興 味ある結果老得ている ${ }^{43}$. 吉木氏らは, An 成分の配 合物を電融法と焼成法*により結晶化させたが，ぞら らの場合汇普通の兏長石のみが得られた。一方，天 然産並びそ合成斜長石の熱膨脹試験孛行ったところ,

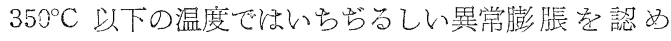
た。これらの実験結果と, 前述の Goldsmith・Davis らの研究と学総合して, 吉木氏らはAn成分の状態図 添第19図のようであるるうと推定した。この図では，

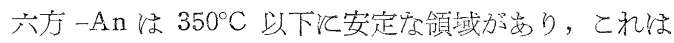
Goldsmith らの見界汇同調するものである。一方， この図では, 斜方 - An 2 全温度範囲を通じて, 準安 定相乞して报われている。

\section{バリウム長石に就いて}

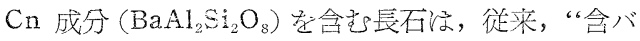
りウム長石 (Barium-bearing ifeldspar)”之総称さ

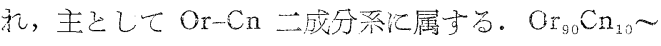

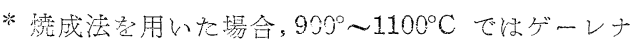
イト結昆の及类生じ， $1200^{\circ} \mathrm{C}$ 以上飞加熱した場 合汇始好て圧長石吢得台礼た。

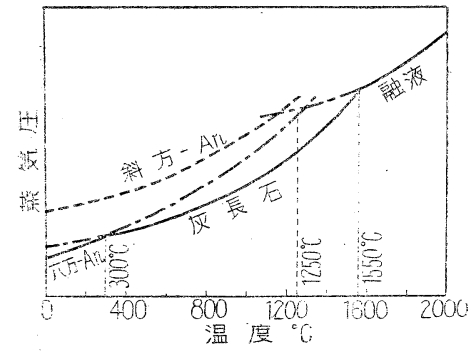

第 19 図 $\mathrm{CaAl}_{2} \mathrm{Si}_{2} \mathrm{O}_{8}$ の状態図（吉木

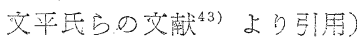

Or $\mathrm{r}_{00} \mathrm{Cn}_{\text {*0 }}$ の悬石はハイアロフェン (Hyalophane), $\mathrm{Cn}$ 飞近い成分のものはセルシアン Celsian)と㭔ばれて

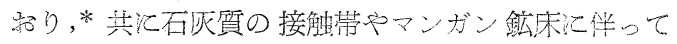

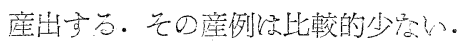

天然産のセルシアンは, 従来, 単斜晶系の通のの文 が知られて蛒り，また，人工的にる古くから天然虐を 同性質の马のが合成されていだ

1942 年飞 Spencer は, 英国Wales 州の水成崖層 中より Cn 成分であって, 乙かも形態斜方晶系汇該 当する結晶を発見した ${ }^{47)}$. 彼はこの新鉱物堂パラセネ シアン (paracelsian) と名づけ, その測角德犯黃玉

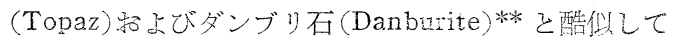

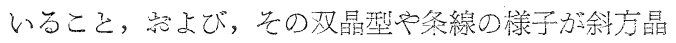
系の対称汇矛盾すること觉指摘した。1952年にSmith は,パラセルシアンの単結晶定用いてX線試験量行い, その内部構造がダンブリ石と極的て類似していること

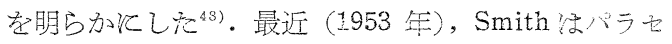

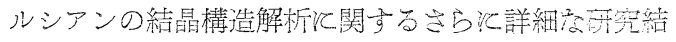
界孝発表し，パラセルシアン结実结単斜晶系結晶で名

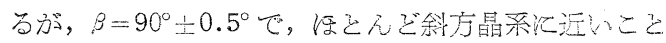
觉明らかにした 光学性との間の矛盾が解決された矛けである。

一方 1951 年飞, 吉木文平博士之松元邦治氏任, 重

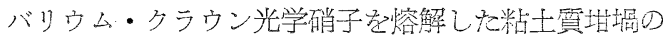
内壁反応部次，六方晶系の大晶（最大 $2 \mathrm{~cm}$ ) 昰生じ ているの登登し，てれがセルシアンの六方晶系置型 体であることを確認して，六方セルシアン (Heracelsian) 々命名して ${ }^{50)}$.ついで, 声木氏等は六方セルシ

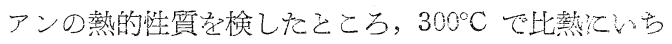
岇るしい変化が起ることがわかり，この附近の温度じ

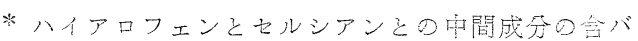

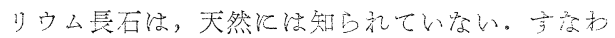

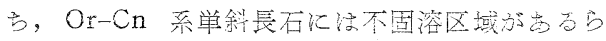

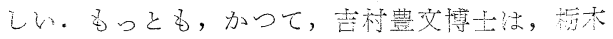

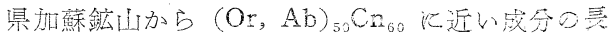

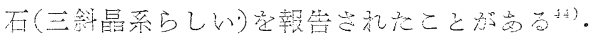

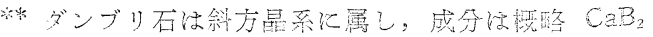

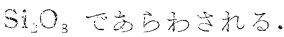




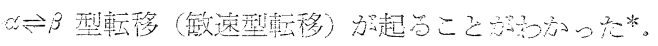

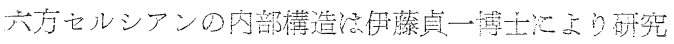

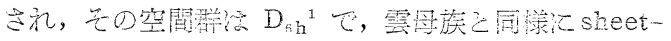

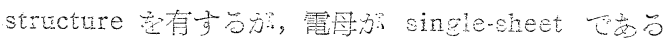

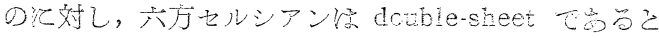
結論した

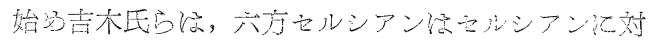

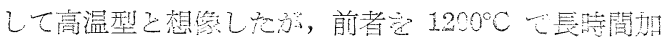

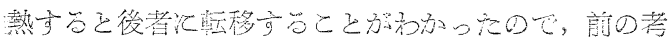

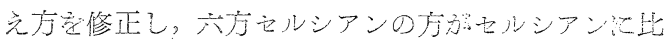

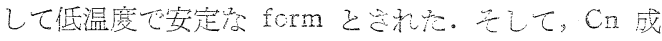

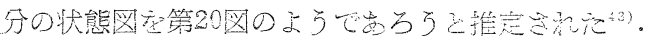

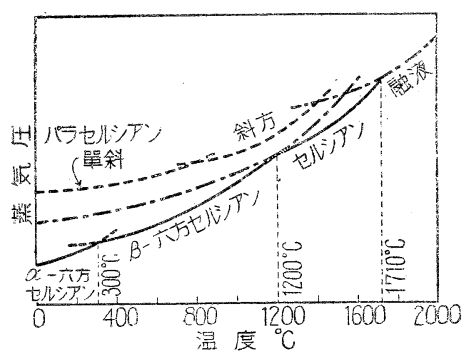

第 20 図 $\mathrm{BaAl}_{2} \mathrm{Si}_{2} \mathrm{O}_{8}$ の状態図（言 木文平民らの 1953 年の文献 ${ }^{43)}$ り引用)

ここに注目ずべは，Cn とAn成分の結晶の相互

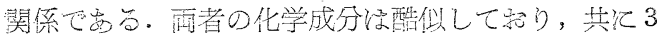

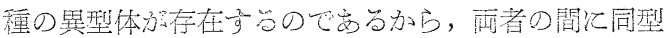

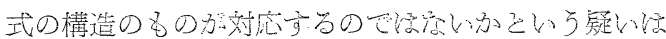

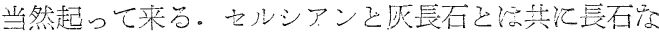
のであるから，内部棈造類似性のめることほ言うき

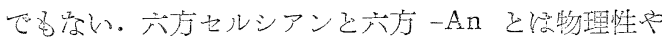
䅂子常数か類似して新门，而者の結晶系舟一致してい

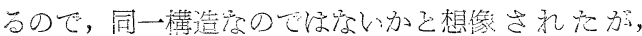

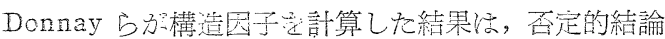

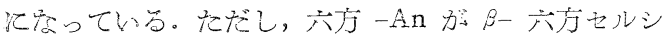

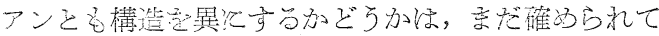

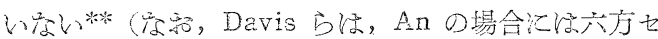
ルシアンと異なり， $\alpha \approx \beta$ 型轱移が起らないこと麦熱 行新尤磪かるた

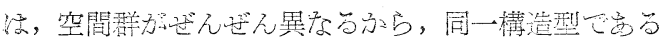
可能性级原W。

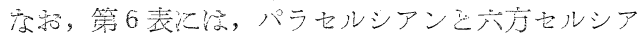

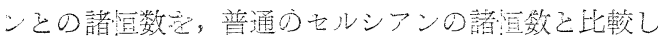
て揭伊て要台。

\section{冬種雪石の鑑别法}

*このことは，後になって Devis と Tutte が竍

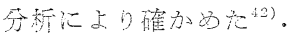

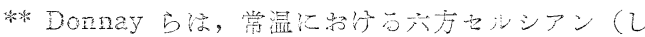

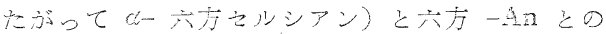

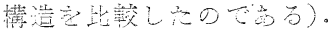

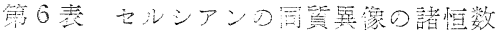

\begin{tabular}{|c|c|c|c|}
\hline & パラセッンアン & 六方さルシアン & セルシアン \\
\hline 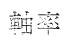 & $0.947: 1: 0.896$ & $\hat{n} \cdot d_{t}$. & $0.658: 1: 0.549$ \\
\hline $\begin{array}{l}\text { 㫟子 } \\
\text { 常数 }\end{array}$ & $\begin{array}{l}a=9.58 \AA \\
b=9.08 \AA \\
c=8.58 \AA \\
Z=4\end{array}$ & $\begin{array}{l}a=5.25 \AA \\
c=7.84 \AA \\
Z=1\end{array}$ & $\begin{array}{l}a=8.36 \AA \\
b=13.10 \AA \\
c=7.29 \AA \\
\beta=116^{\circ}\end{array}$ \\
\hline 模学 & $\begin{array}{l}c=1.5702 \\
\beta=1.5824 \\
\gamma=1.5869 \\
2 V=5035^{\prime} \\
\text { 光学悖 : 僓 }\end{array}$ & $\begin{array}{l}\omega=1.373 \\
\varepsilon=n . d . \\
\text { 光学暗 : 正 }\end{array}$ & $\begin{array}{l}\alpha=1.587 \\
\beta=1.593 \\
\gamma=1.600 \\
2 \mathrm{~V}=87^{\circ} \\
\text { 光学性: 王 }\end{array}$ \\
\hline
\end{tabular}

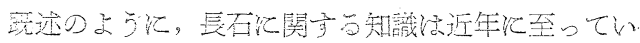

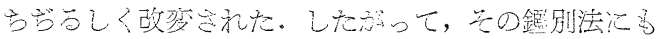

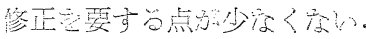

舖長石添 ( $\mathrm{Ab}-\mathrm{An}$ 系) 2アル力り長石系 (Or-Ab

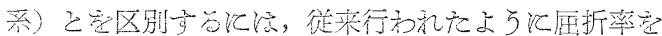

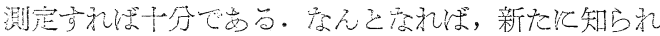

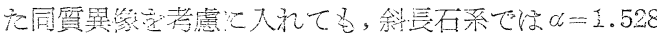
１.575; $r=1.539 \sim 1.590$, アル力り長石系てい $\alpha=$ $1.518 \sim 1.529 ; r=1.522 \sim 1.539$ となり，浜さんご重

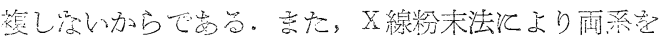

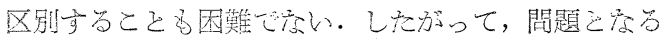

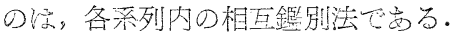

(1) 斜長石系の鑑别法斜長石系の詳細な成分索

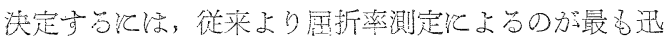
速，かつ，正確でらうこされた、このことは，斜長石

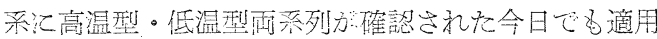

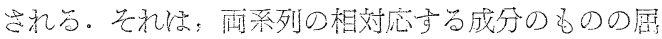

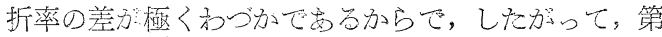

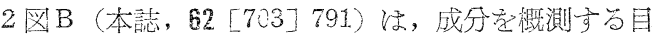

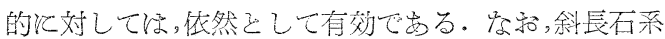

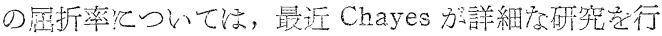

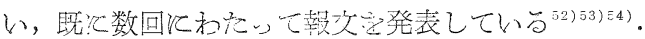

一方，屈折率測定の多により，与光られた斜長不加 高温型。低温型画系列のいずれに属するかを決定する

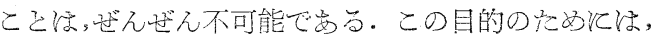

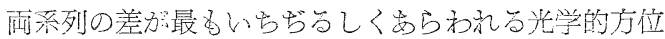

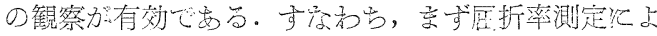
り化学成分夌概测し，その上てケーラ一角等の光学的

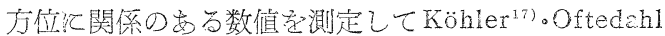
18)・Reynolds ${ }^{20}$ bと子り作製された図索参照して目的

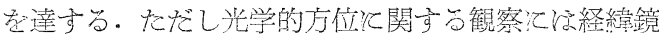

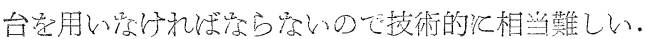

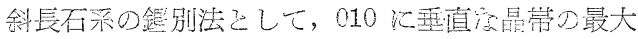

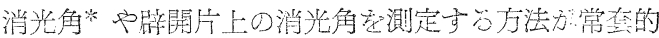

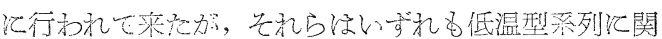

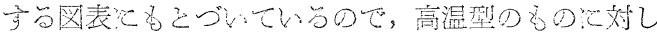




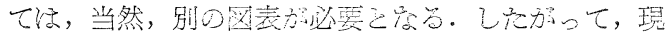

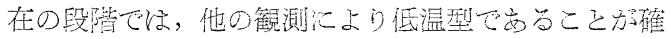
認されて場合以外飞適用して浪険で岕る。

X線粉末試験法化より斜長不の両系列老区別するの

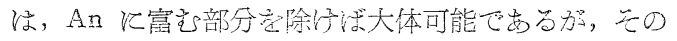

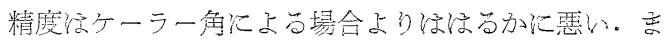
た，各系列の詳細萦成分定決定することも，ぜれぜん

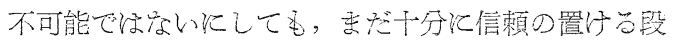

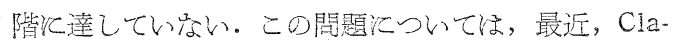
isse ${ }^{55)}$, Goodyear 预よび Duffin ${ }^{21}$ らの研究がある。

(2) アルカリ長石系の鑑别法 既述のよう飞、ア ルカリ長石系は, 关の同質晎像間の関係がまだほっき

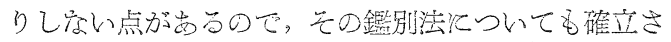
れたもの注ない。また，アル方り長石系の屈折率諒， 斜長石系江比して変化範圈加いちら゙るしくせまいの

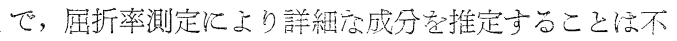
適当である。

Tuttle 1952 年汇,アルカリ長石系の成分在決定 する良方法学発見した ${ }^{28}$. す空方ち，問題のアルカり 長石を加熱して高温型玻黎長石一高温型ソーダ長石菜 のものに䎐移させ，乙かる後 $d_{(\overline{2} 01)}$ の值を測定して， 第10図（本誌，63［704］20）により成分を出すので ある.Tuttle 自身，この方法放多くのアルカリ長

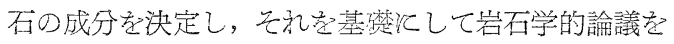
行っている ${ }^{36) 37}$. Tuttle 涫, 禿た, 前述の方法てアル カリ長石の成分走浃定した後, 別反原試料（加熱しな

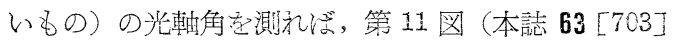

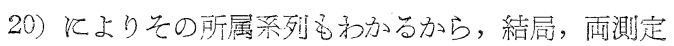
老併用してアルカり長石を完全核鑑别できると言って

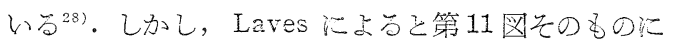

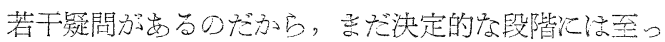
ていない。

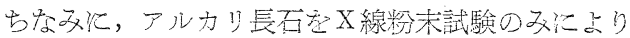
鑑別する方法々，亲方聞いてい宗い。

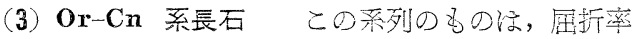
と光軸角とを併せて測定することにより，斜長石系・ アルカリ長石系のものと区別てきる, また最近, Vermaas はX線的にこの系列の成分起決定する方法尼発 表している ${ }^{58}$.

(4) 六方 $-\mathrm{An}$ ・斜方 $-\mathrm{An}$ ・六方セルシアン・パラセ ルシアン等ここれら䄈, 他の長石とは全然内部構造 公異にするから，X線的纪区別できるし，光学的鑑別 も困難てない。

\section{結武}

*この值は，アルバイト式双晶をなす斜長石につい ては，薄片下で坆镜的簡単に測定できるので便利 でるる。

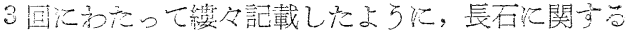

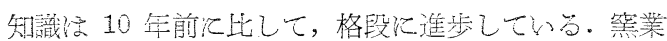
工学汇携的方技術者・研究者諸賢加，長石原料羑吟味 したり，長石を含む実験データ整理されたりするの

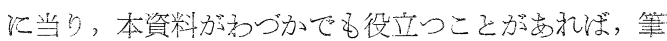

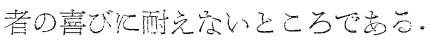

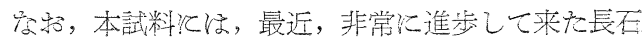
の結晶構造汇関する專項を症とえぞ省いた。气れね， この間題が極好て難解で，乙た少っって一般向きでない

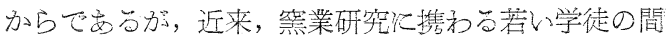

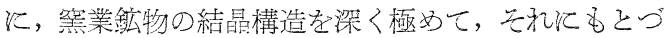
いて䈉業技術化新分野を開こうとする傾向が見受けら れるようゼあから（とれは，非常に喜ばしい現象で

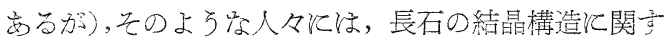
るChao・Taylor・Cole・Gay 等の最近の論文老研究す

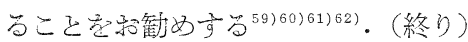

$$
\text { 引用交献 }
$$

40) G. Donnay, Acta Cryst., 5153 (1952)

41) J.R. Goldsmith and E.G. Ehlers, Jour. Geol., 60 386-397 (1952)

42) G.L. Davis and O.F. Tuttle, Amer. Jour. Sci., (Bowen Volume, I) 107-114 (1952)

43) 吉木交平・小出重明・脇正教, 旭硝子研究報告, III 135-147 (1953)

44) T. Yoshimura, Jour. Geol.Soc. Jap., 18877 (1936)

45) P. Eskola, Amer. Jour. Sci., 4 331-375 (1922)

46) R.H. Thomas, Jour. Amer. Ceram. Soc., 33 35-44 (1950)

47) I.J. Spencer, Miner. Mag., 26, 231-245(1942)

48) J.V. Smith, Amer. Jour. Sci., (Bowen Volume, II), 513-515 (1952)

49) J.V. Smith, Acta Cryst., 6 613-620 (1953)

50) B. Yoshiki and K. Matsumoto, Jour. Amer, Ceram. Soc., 34 283-286 (1951)

51) T. Ito, Maruzen Co., Ltd., 19-29 (1950)

52) F. Chayes, Jour. Geol, 58 593-595 (1950)

53) F. Chayes, Amer. Jour. Sci., (Bowen Volume, I), $85-105$ (1952)

54) F. Chayes, Amer. Jour. Sci., 252 172-179 (1954)

55) F. Claisse, Amer. Miner., 35 412-420 (1950)

56) O.F. Tuttle, Jour. Geol., 60 107- (1952)

57) O.F. Tuttle and M.L. Keith, Geol. Mag, $9161-72$ (1954)

58) F.S.H. Vermaas, Amer Miner, 38 845-857 (1953)

59) S.H. Chao and W.H. Taylor, Ray. Soc. A, 176 76-87 (1940)

60) W.F. Cole, H. Sörum, and W.H. Taylor, Acta cryst., 4 20-29 (1951)

61) P. Gay and W.H. Taylor, Acta cryst., \& 647-650 (1953)

62) P. Gay, Miner. Mag., 30 169-177 (1953)

$$
\text { 正愦 }
$$

62〔703]790 左 13 行 そ礼をつ礼ては それにつ れて, 同 791 左 7 8 行 酸性深成岩(花嵐岩・片麻岩・ 熱変成岩) は酸性深成岩（花骨岩など）や片麻岩・熱変 成岩, 同 791 左 37 行 An 飞近い成分は $\mathbf{A b}$ に近い 成分，同 795 右 3 行 次号《は考次号よりはと訂正.

63[704]21 第 16 図の説明中 Or-Ab 系 1，综 $\mathrm{Or}-\mathrm{Ab}$ 系で，と先れ炎れ訂正。 